\title{
Association of inflammatory biomarkers with lung cancer in North Indian population
}

\author{
Priyanka Gaur ${ }^{1}$, Sandeep Bhattacharya ${ }^{1}$, Surya Kant ${ }^{2}$, R.A.S. Kushwaha ${ }^{2}$, Rajiv Garg ${ }^{2}$, \\ Gaurav Singh ${ }^{3}$, Sarika Pandey ${ }^{2}$, Supriya Sharma ${ }^{4}$
}

1. Department of Physiology, King George's Medical University, UP, Lucknow-226010, Uttar Pradesh, India.

2. Department of Respiratory Medicine, King George's Medical University, UP, Lucknow -226010, Uttar Pradesh, India.

3. CSIR-Institute of Genomics and Integrative Biology, Delhi.

4. Department of Oral Pathology and Microbiology, King George’s Medical University, UP, Lucknow-226010, Uttar Pradesh, India.

\begin{abstract}
:
Background: Lung cancer is characterized by uncontrolled cell growth of the lung tissues. It is the leading cause of cancer-related deaths worldwide.

Objectives: The study aimed to determine the circulating CRP, TNF- $\alpha$, IL- 6 and IL- 8 levels in lung cancer and healthy control and also established association between these biomarkers with the smoking status as well as the stages of the disease.

Methodology: 51 lung cancer patients and 51 healthy controls were enrolled in this case-control study. The serum levels of CRP, TNF- $\alpha$, IL- 6 and IL- 8 were measured in lung cancer patients and healthy control groups.

Results: The levels of serum CRP, TNF- $\alpha$, IL-6 and IL- 8 were significantly higher in lung cancer patients when compared with controls $(\mathrm{P}<0.0001)$. The levels of these biomarkers were also significantly higher in stage iii/iv as compared to stage $\mathrm{i} /$ ii $(\mathrm{P}<0.001)$. Significant difference in the levels of these biomarkers were also found in smoker and non-smoker lung cancer patients as compared to controls $(\mathrm{P}<0.001)$.

Conclusion: CRP, TNF- $\alpha$, IL-6 and IL-8 are the promising biomarkers in the identification of lung cancer patients. The study also supports the association of inflammatory markers to lung cancer risk. Hence these findings suggest the levels of these biomarkers could be a useful tool for guiding the diagnosis of lung cancer.

Keywords: Lung cancer, biomarker, inflammation, stage, smoking.

DOI: https://dx.doi.org/10.4314/ahs.v19i2.39

Cite as: Gaur P, Bhattacharya S, Kant S, Kushwaha RAS, Garg R, Singh G, Pandey S, Sharma S. Association of inflammatory biomarkers with lung cancer in North Indian population. Afri Health Sci.2019;19(2): 2147-2155. https:// dx.doi.org/10.4314/ahs.v19i2.39
\end{abstract}

\section{Introduction}

Lung cancer is characterized by uncontrolled cell growth of the lung tissues. It is the leading cause of cancer-related mortality worldwide ${ }^{1}$. Cytokines are soluble polypeptides and glycoprotein produced by immune cells, which can act locally or systemically in different cell types and triggering signalling pathways responsible for cell acti-

\section{Corresponding author:}

Sandeep Bhattacharya, Department of Physiology,

King George's Medical University, Lucknow- 226010, Uttar Pradesh, India

Email:sbhattachya@gmail.com vation, proliferation, growth, differentiation, migration and cytotoxicity ${ }^{2,3}$. Cytokines involved in the activation of immune effectors mechanisms which results to limit the tumour growth as well as they also play role in the process of malignant transformation, tumour growth, invasion and metastasis ${ }^{4}$. It has been suggested that the characteristic patterns of cytokines have been found in different cancer patients, which can be related to their diagnosis, prognosis as well as prediction of treatment responses and survival ${ }^{5}$. Interleukin 6 (IL-6) is known as a multi-functional cytokine which plays a central role in the host defense mechanism in regulating immune responses, acute phase reactions and haematopoiesis ${ }^{6}$. It has been reported that IL- 6 is an autocrine growth factor for renal cell carcinoma ${ }^{7,8}$. IL-6 is produced by other non-haemato- 
poietic tumour cells, including bladder carcinoma ${ }^{9}$, ovarian carcinoma ${ }^{10}$ and glioblastomas ${ }^{11}$. It has been suggested that circulating pro-inflammatory cytokines may be associated with lung cancer. Interleukin 6 (IL-6) and interleukin 8 (IL-8) are expressed in premalignant epithelial cells and their expression is associated with a poor prognosis of lung cancer patients ${ }^{12,13}$. Higher levels of circulating IL-6 and IL-8 were reported in lung cancer ${ }^{14-17}$, higher expression of IL-8 was reported in small-airway epithelial cells in smokers and Elevated levels of serum IL-6 and IL-8 were also found in smokers ${ }^{18-20}$. TNF- $\alpha$ is an important immune regulatory factor which has the toxic effects on tumor cells and inhibits the tumor growth ${ }^{21}$. It has been supposed that TNF- $\alpha$ could help to maintain the metabolic as a protective response to external stress whereas excess TNF- $\alpha$ would lead to inflammatory and septic shock. CRP is an acute-phase protein, produced in the liver in response to elevated cytokine levels after an inflammatory stimulus ${ }^{22}$. It has been found that "acutephase response" is also seen in a variety of diseases such as cardiovascular disease, diabetes, systemic inflammatory diseases, some autoimmune disorders and cancer $^{23,24}$. CRP levels have also been used to predict cancer risk, detect cancer recurrence and determine prognosis ${ }^{25-27}$. Elevated preoperative serum CRP has been identified to be a significant prognostic factor in patients with colorectal, esophageal and hepatic carcinoma. Previous studies have shown that NSCLC Patients with elevated preoperative serum CRP levels has experienced worse survival than those patients with undetectable levels of $\mathrm{CRP}^{28-30}$. It is well known that chronic inflammation is associated with lung carcinogenesis. C-reactive protein (CRP) a systemic marker of chronic inflammation which is associated with increased lung cancer risk ${ }^{31-35}$. Serum biomarkers offer a simple, non-invasive, cheap and reliable tool for more efficient lung cancer management. The serum of lung cancer patients will most likely reveal many proteins that may be used as biomarkers. This study aimed to determine the association of circulating biomarkers with the lung cancer and also assessed the relationship between these biomarkers with the smoking and stage of the lung cancer.

\section{Material and methods}

This case control study was conducted between March 2015 to January 2017 at the Department of Respiratory Medicine, King George’s Medical University, Lucknow,
India. This study was approved by the ethics committee of the institution and participants gave their written informed consent. A total of 51 histopathologicaly confirmed lung cancer patients were enrolled in this study after excluding those having other disorders such as COPD, asthma, tuberculosis, interstitial lung disease and 51 healthy controls were also enrolled to compare the serum CRP, IL-6, IL- 8 , TNF- $\alpha$ level of both the groups. Healthy age and sex matched subjects without pervious medical history of respiratory and other disorders seen by their practitioner during regular checkup were recruited consecutively as controls.

Peripheral blood samples of lung cancer patients and controls were collected into the plain vial by venipuncture on first admission before chemotherapy. The blood sample was clotted at room temperature. Serum samples were obtained by centrifugation at 3,000 rpm for $10 \mathrm{~min}$ and stored at $-80^{\circ} \mathrm{C}$ until use. Serum Levels of CRP levels of lung cancer patients and healthy controls were estimated. Serum Levels of IL-6, IL-8 and TNF- $\alpha$ were determined using determined using a commercially available ELISA kit according to the manufacturer's instructions. Data were analyzed using Graph Pad Prism version 5 (Graph Pad software Inc.; La, Jolla, CA, USA). and the graphs were drawn into the excel. All demographic and clinical data were expressed as mean \pm standard error of the mean (SEM) and percentage. The chi-square test was used for categorical data and groups were compared by unpaired t-test or one-way analysis of variance (ANOVA). The Bonferroni test was applied for multiple comparisons. $\mathrm{p}$ value of $<0.05$ were considered significant.

\section{Results}

The demographic and clinical characteristics of lung cancer patients and controls are shown in Table 1. The mean age of the lung cancer patients and control group were not showing significant different $(\mathrm{p}=0.392)$. Out of 51 lung cancer patients $41(80.4 \%)$ was male and rest $10(19.6 \%)$ are female. A significant difference was found in smoking history of lung cancer patients and control $(p=0.01)$. It has been observed that the weight and BMI were lower in lung cancer patients as compared to controls and this difference is statistically significant $(p<0.0001)$. Statistically significant difference has been observed in the pack year of lung cancer patients as compared to controls $(\mathrm{p}<0.0001)$. 
Table 1: Demographic characteristics of Lung cancer patients and control

\begin{tabular}{|c|c|c|c|}
\hline Parameters & Lung Cancer $(\mathrm{N}=51)$ & Controls $(\mathrm{N}=51)$ & P value \\
\hline Age & $54.43 \pm 1.87$ & $52.33 \pm 1.57$ & $0.392^{\mathrm{a}}$ \\
\hline \multicolumn{4}{|l|}{ Sex } \\
\hline Male & $41(80.4 \%)$ & $39(76.5 \%)$ & $0.630^{\mathrm{b}}$ \\
\hline Female & $10(19.6 \%)$ & $12(23.5 \%)$ & \\
\hline Height & $159.2 \pm 1.1$ & $158.1 \pm 0.95$ & $0.4518^{\mathrm{a}}$ \\
\hline Weight & $47.57 \pm 1.1$ & $56.18 \pm 1.2$ & $<0.0001^{\mathrm{a}}$ \\
\hline BMI & $18.73 \pm 0.35$ & $22.57 \pm 0.53$ & $<0.0001^{\mathrm{a}}$ \\
\hline \multicolumn{4}{|l|}{ Smoking History } \\
\hline Smoker & $37(72.55 \%)$ & $23(45.10 \%)$ & $<0.01^{\mathrm{b}}$ \\
\hline Non Smoker & $14(27.5 \%)$ & $28(54.9 \%)$ & \\
\hline Pack Year & $36.84 \pm 4.95$ & $15.30 \pm 1.15$ & $<0.001^{\mathrm{a}}$ \\
\hline \multicolumn{4}{|l|}{ Histology } \\
\hline Adenocarcinoma & $27(52.9 \%)$ & - & - \\
\hline Squamous Cell Carcinoma & $19(37.3 \%)$ & & \\
\hline Small Cell Carcinoma & $2(3.9 \%)$ & & \\
\hline $\mathrm{NSCC}$ & $3(5.9 \%)$ & & \\
\hline \multicolumn{4}{|l|}{ Stage } \\
\hline $\mathrm{I} / \mathrm{II}$ & $8(15.7 \%)$ & - & - \\
\hline III/IV & $43(84.3 \%)$ & & \\
\hline
\end{tabular}

Data were expressed in mean \pm standard error of the mean (SEM). a Unpaired t-test, b chi-square test. $\mathrm{p}<0.05$ are considered significant.

Comparison of serum levels of CRP, TNF- $\alpha$, IL-6 and IL-8 between Lung Cancer patients healthy controls

The mean level of CRP in lung cancer patients was 22.43 \pm 1.55 and healthy controls was $3.69 \pm 0.384$, level of tnf- $\alpha$ in lung cancer patients was $53.66 \pm 3.50$ and healthy controls was $19.56 \pm 0.643$, level of IL-6 in lung cancer patients was $44.13 \pm 3.86$ and healthy controls was 9.97 \pm 0.49 and level of IL-8 in lung cancer patients was 40.28 \pm 3.91 and healthy controls was $10.44 \pm 0.57$. Levels of inflammatory cytokines such as CRP TNF- $\alpha$, IL-6 and IL-8 were elevated in lung cancer patients as compared to 


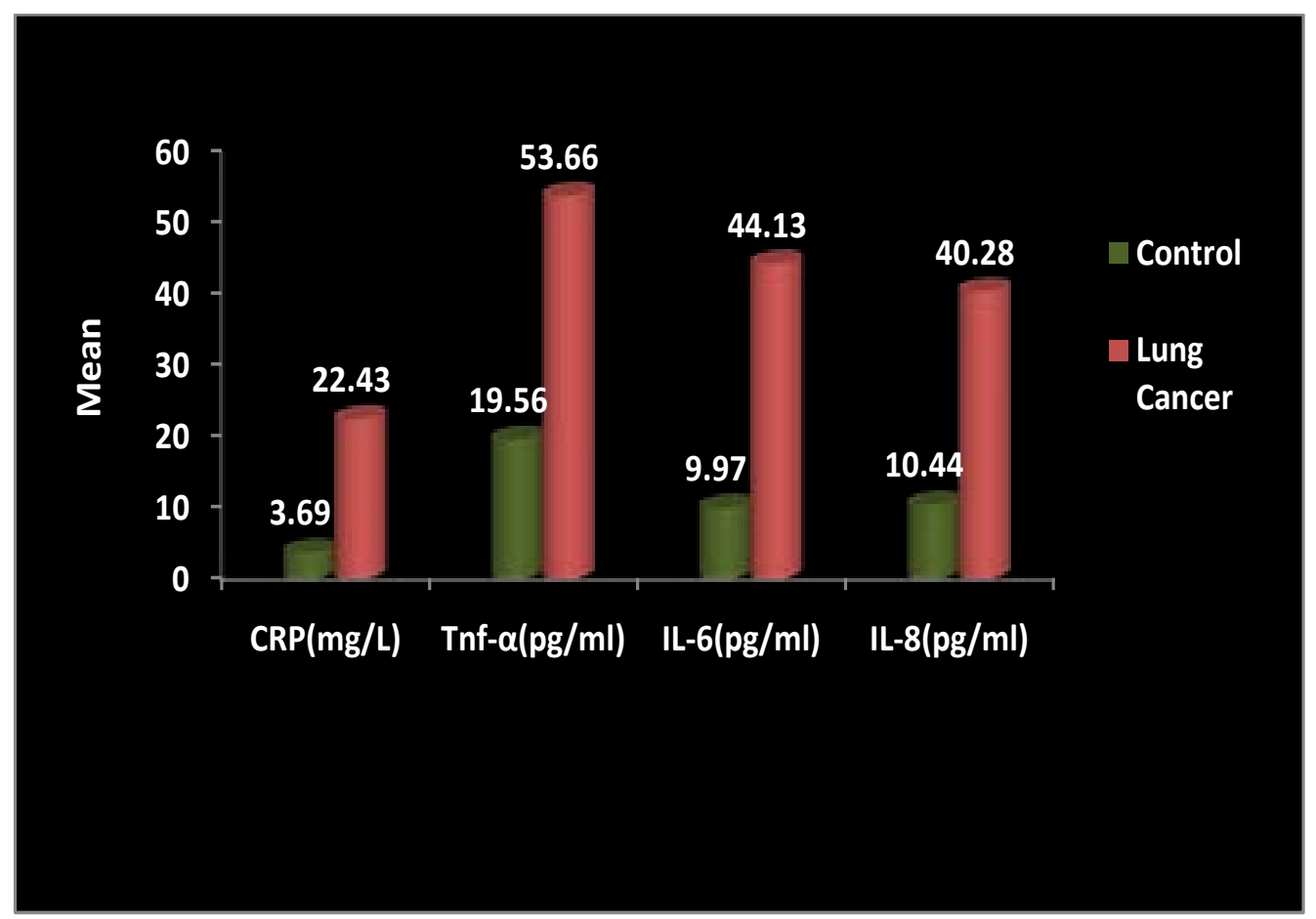

Figure 1: Comparison of serum CRP, TNF- $\alpha$, IL6 and IL-8 Levels between lung cancer patient and healthy controls. Data are expressed as mean and compared by unpaired t-test. p-values $<0.05$ are considered significant.

Comparison of serum levels of CRP, TNF- $\alpha$, IL-6 and IL-8 among different stages of lung cancer patients and healthy control groups:

The serum CRP,TNF- $\alpha$, IL-6 and IL-8 levels of Lung Cancer patients in stage III/ IV was significantly higher than stage I/ II and healthy controls (Data represented in Fig. 2). The study also shows that the significant difference were found in the serum CRP levels in Stage i/ ii Lung cancer when compared to stage iii/iv Lung cancer $(p<0.01)$, stage $i /$ ii Lung cancer when compared to healthy control $(\mathrm{p}<0.01)$ and stage iii/iv Lung cancer when compared to healthy controls $(p<0.001)$. The serum TNF- $\alpha$ level of patients in stage III/IV was higher than these in controls and stage I/II. Significant difference were obtained in the levels of TNF- $\alpha$ in stage iii/ iv Lung cancer when compared to stage $\mathrm{i} /$ ii Lung cancer $(\mathrm{p}<0.001)$ and stage iii/iv Lung cancer when compared to healthy control) $(\mathrm{p}<0.001)$. In the serum IL6 levels the significant difference was found in stage iii/iv Lung cancer when compared to stage i/ii Lung cancer $(\mathrm{p}<0.01)$ and stage iii/iv lung cancer compared to healthy control $(p<0.001)$. significant difference were obtained in the Serum IL8 levels of stage iii/iv Lung cancer when compared to stage $\mathrm{i} /$ ii Lung cancer $(\mathrm{p}<0.01)$ and stage iii/iv Lung cancer when compared to Healthy Control $(\mathrm{p}<0.001)$. 


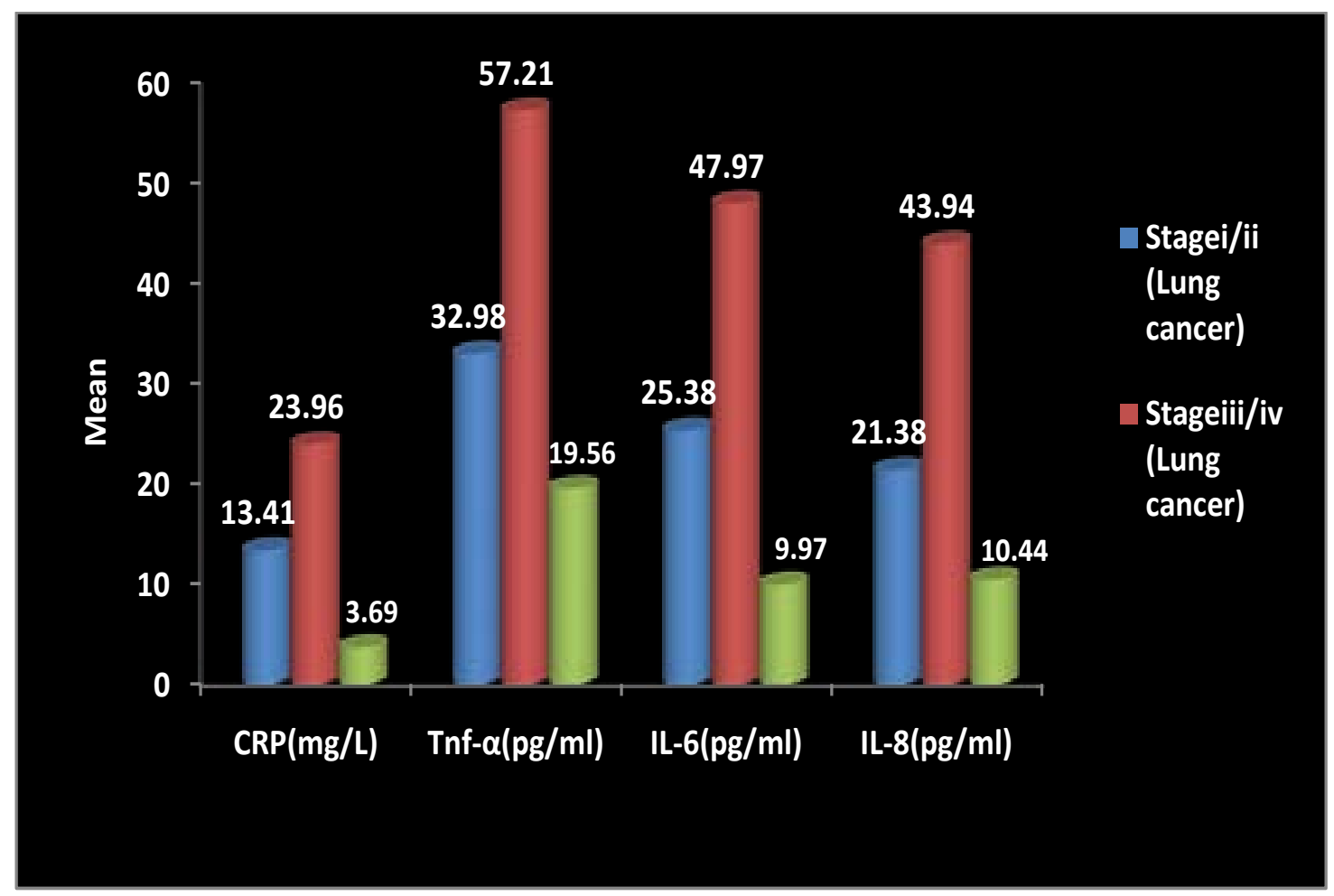

Figure 2: Comparison of Serum CRP, TNF- $\alpha$, IL-6 and IL-8 between Different Stages of Lung Cancer and Healthy Controls. Data presented as mean and compared by one-way analysis of variance (ANOVA) followed by Boneferroni post-test for multiple comparisons. $p$-values $<0.05$ are considered significant.

Comparison of serum levels CRP, TNF- $\alpha$, IL-6 and IL-8 between smokers and non- smokers lung cancer patients with smokers and non-smokers healthy control groups:

Levels of serum CRP,TNF- $\alpha$, IL-6 and IL- 8 between smokers and non- smokers lung cancer patients and control were compared ( data represented in fig 3). It has been observed that higher serum levels of CRP, TNF- $\alpha$, IL- 6 and IL- 8 were observed in smokers as compared to non-smokers both in lung cancer patients and controls. In the serum CRP levels, Significant difference were found in the non-smoker lung cancer patients when compared to non smokers controls $(\mathrm{p}<0.001)$, Smokers/ Ex-smokers control $(\mathrm{p}<0.01)$ and smokers/ Exsmokers lung cancer when compared to non-smokers Control $(\mathrm{p}<0.001)$, Smokers/ Exsmokers Control $(p<0.001)$ and non smok- ers Lung cancer $(p<0.001)$. Significant difference were found in the serum Tnf- $\alpha$ levels of smokers/ ex- smokers lung cancer patients when compared with non-smokers lung cancer $(\mathrm{p}<0.001)$ non-smokers $\operatorname{control}(\mathrm{p}<0.001)$ and smokers/ex-smokers control $(p<0.001)$ also significant difference were found when non-smokers lung cancer patients was compared to non-smokers healthy control subjects $(p<0.01)$. Significant difference were also found in the serum IL6 levels in smoker/ex-smoker Lung cancer patients when compared with non-smokers Lung cancer $(\mathrm{p}<0.001)$, smokers/ ex-smokers control $(p<0.001)$ and non-smokers control $(p<0.001)$. Serum IL8 levels also shows the significant difference when compared to smoker/ex-smokers Lung cancer patients with non-smokers Lung cancer patients $(\mathrm{p}<0.001)$, smokers/ ex-smokers control $(\mathrm{p}<0.001)$ and non-smokers control $(\mathrm{p}<0.001)$. 


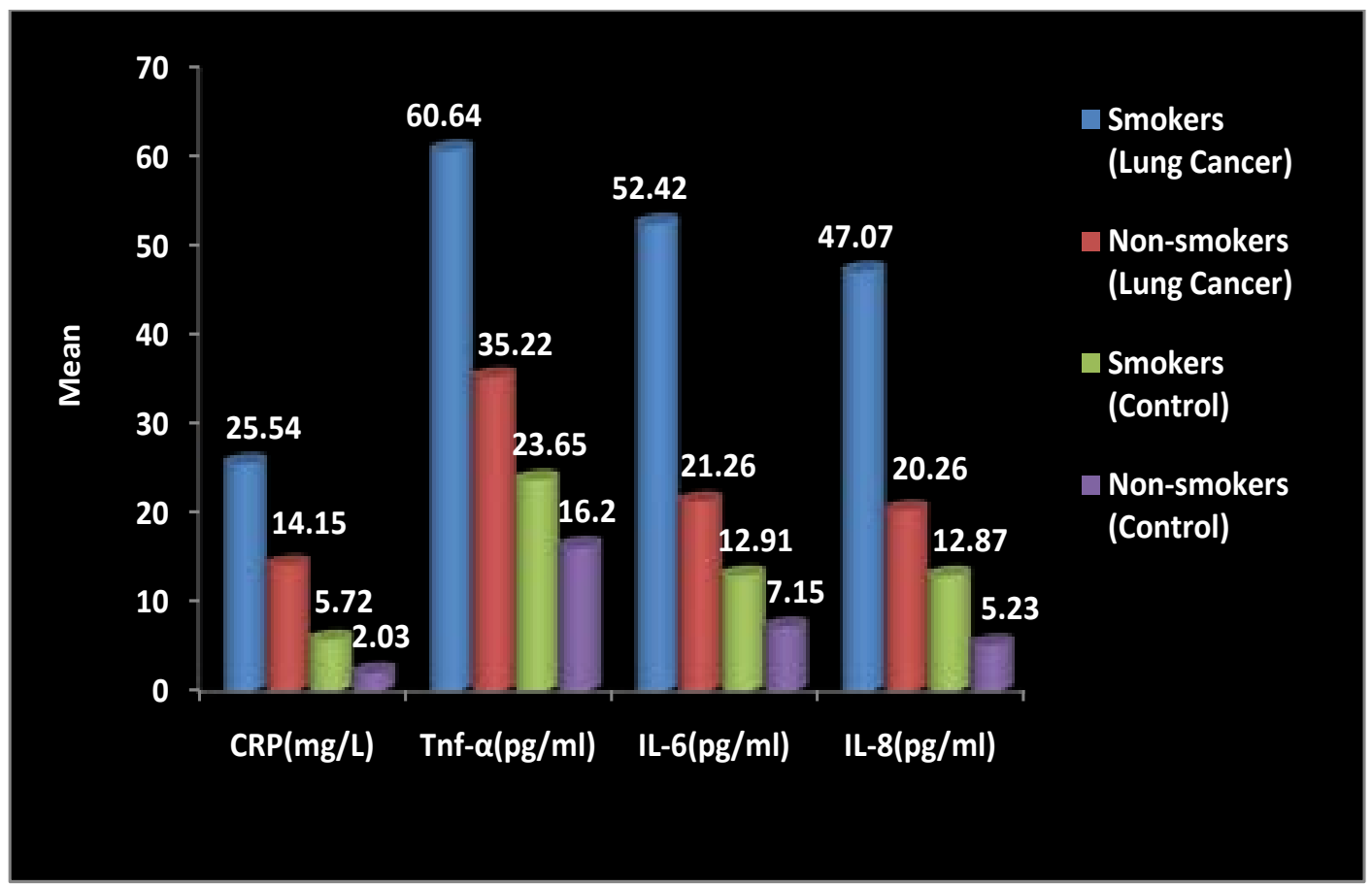

Figure 3: Comparison of Serum CRP, TNF- $\alpha$, IL-6 and IL-8 Levels Between Smokers and Non-smokers lung cancer patients and Smokers and Non-smokers Healthy controls. Data presented as mean and compared by one-way analysis of variance (ANOVA) test followed by Bonferroni post-test for multiple comparisons. $\mathrm{p}$-values $<0.05$ are considered significant

\section{Discussion}

It has been suggested from the accumulating evidences that chronic inflammation is involved in the development and progression of cancer. The immune system of the lung is represented by cells and cytokines, which have different functions under physiological conditions. The dynamics of these elements is stable and the ratio of immune cells and cytokines remains within the normal limits, as a result there is no generation of harmful responses to the host. Certain unbalances in these physiologic immune responses, caused by lung cancer can serve as biomarkers and predictive factors in relation to immunotherapy ${ }^{36}$. Since inflammation can be also triggered by a variety of pathogens as well as the environmental factors ${ }^{37}$. Once the lung is vulnerable to these pathogens pathogens and gaseous pollutants, the persistent exposure to these factors can trigger the production of cytokines that result a chronic inflammatory environment which is capable to induce cell transformation as well as subsequent tumor growth $^{37,38}$. Various biological processes such as proliferation, differentiation, migration, activation, and cell growth are coordinated by cytokines as well as the tumor development ${ }^{39,40,41}$. Cytokines may contribute to tumor development by stimulating cell growth and differen- tiation as well as inhibiting the apoptosis of abnormal cells $^{42}$. Previous studies have shown that the cytokines in several biological fluids such as plasma can reflect various diseases including cancer ${ }^{43}$. The inflammation caused by immune system activation is likely linked to carcinogenesis by promoting angiogenesis and proliferation of tumour cells $\mathrm{s}^{42,12}$ according to the cytokine profile in the tumour microenvironment ${ }^{8,44-47}$. It is suggested that inflammatory cytokines released through inflammatory response may promote tumor growth which further with advanced non- stimulate the inflammatory response ${ }^{48}$. Previous studies shows that the Serum CRP levels have been found to be highly elevated in lung cancer patients when compared with healthy control ${ }^{23,49}$. It has been also reported from some previous studies that increased serum CRP levels were found in patients of small cell lung carcinoma ${ }^{50}$. It has been suggesting that the inflammatory cytokines may have the potential to act as biomarkers of lung cancer ${ }^{51}$. In the present study the serum levels of CRP, TNF- $\alpha$, IL- 6 and IL- 8 seem to be higher in the lung cancer patients as compared to healthy controls. These findings are similar with some other previously reported studies ${ }^{52,53}$. Some recent studies suggested that serum concentrations of IL- 6 and IL- 8 were also found to be 
increased in lung cancer patients as compared with control $^{54,55}$. Serum IL-8 levels were found to be significantly elevated in lung cancer patients with respect to controls. IL-8 serum levels were also found to be significantly increased in stage III/IV patients as compared with stage I/II patients. It has been reported that the serum TNF- $\alpha$ levels and IL- 8 were found increased along with the advanced stages of lung cancer suggesting a possible local production of inflammatory cytokines which is also in accordance with some previous studies ${ }^{56}$. The higher levels of these inflammation biomarkers were observed in smokers/ex-smokers as compared with non-smokers in lung cancer patient and control.The higher levels of inflammatory biomarkers in lung cancer patients regardless of smokers or no-smokers indicate that their increase is not only due to tobacco use but also affected by lung cancer. Since Identification of biomarkers of increased cancer risk are highly warranted as they may help us in target screening programs toward the high risk individuals facilitating prevention of cancer or diagnosis of cancer at a time when curative treatment is still possible. This study is an attempt to build a prognostic inflammatory-based classifier for the lung cancer. These inflammation cytokines can serve as biomarkers and predictive factors in relation to the immunotherapy.

\section{Limitation of the study}

The limitation of the study is low sample size. The levels of these inflammatory biomarkers were not estimated before and after the chemotherapy. Further study may be done with large sample size and long term follow-up period at different time intervals.

\section{Conclusion}

The present study concluded that the serum CRP, TNF- $\alpha$, IL-6 and IL-8 levels were significantly higher in the patients with lung cancer as compared to control. The higher levels of all these four inflammation biomarkers were observed in smokers as compared with non-smokers. This indicates that tobacco smoking play a pivotal role in inflammatory processes, thereby contributing to lung cancer etiology. It has been demonstrated that Chronic inflammation plays an important role in lung cancer. The understanding of the role of chronic inflammation in the pathogenesis of lung cancer may have an important clinical diagnostic and prognostic implication

\section{Acknowledgement}

We are greatly thankful to department of Physiology for providing necessary facilities for carrying out the study. We are also appreciating the patients and the healthy volunteers who were participating in this study.

\section{Conflict of interest}

None declared.

\section{References}

1. Siegel R, Ma J, Zou Z, Jemal A .Cancer statistics. CA Cancer J Clin. 2014;64(1): 9 PubMed -29.

2. Mack CL.Serum cytokines as biomarkers of disease and clues to pathogenesis. Hepatology. 2007;46 (1):6 PubMed -8 .

3. Seruga B, Zhang H, Bernstein LJ, Tannock IF.Cytokines and their relationship to the symptoms and outcome of cancer. Nat Rev Cancer. 2008; 8(11): 887 PubMed -899.

4. Smyth MJ, Cretney E, Kershaw MH, Hayakawa Y. Cytokines in cancer immunity and immunotherapy. Immunol Rev. 2004; 202(1):275-293. PubMed

5. Chang CH, Hsiao CF, Yeh YM, Chang GC, Tsai YH, et al.Circulating interleukin-6 level is a prognostic marker for survival in advanced nonsmall cell lung cancer patients treated with chemotherapy. Int J Cancer. 2013;132(9):1977 -1985. PubMed

6. KishimotoT. Thebiology of interleukin-6. Blood.1989;74(1):1 -10. PubMed

7. Koo As, Armstrong C, Bochner B, Shimabukuro T, Tso Cl, Dekernion Jb And Belldegrum A. Interleukin-6 and renal cell cancer production, regulation and growth effects,Cancer Immunol. Immunother. 1992;35(2) :97 PubMed -105.

8. Miki S, Iwano M, Miki Y, Yamamoto M, Tang B, Yokokawa K, Sonoda T, Hirano T And Kishimoto T. IL-6 functions as an autocrine growth factor in renal cell carcinomas. FEBS Lett. 1989;250(2):607 PubMed -610.

9. Rawle Fc, Shields J, Smith Sh, Liescu V, Merkenschlager M, Beverly Pcl And Callard Re. B cell growth and differentiation induced by supernatants of transformed epitheal cell lines. Eur. J. Immnol. 1989; 16(8):1017 PubMed -1019.

10. Watson Jm, Sensrntaffar J1, Berek Js and Martinez-Maza O. Constitutive production of interleukin 6 by ovarian cancer cell lines and by primary ovarian tumor cultures. Cancer Res. 1990;50(21):6959 PubMed -6965.

11. Meir Ev, Sawamura Y, Diserens Ac, Hamou Mf And 
De Tribolet N. Human glioblastoma cells release interleukin6 in vivo and in vitro. Cancer Res. 1990; 50(20):6683 PubMed -6688

12. Davalos AR, Coppe JP, Campisi J, et al. Senescent cells as a source of inflammatory factors for tumor progression. Cancer Metastasis Rev. 2010; 29 (2)273-283.

13. Seike M, Yanaihara N, Bowman ED, et al. A cytokine gene signature of the lung adenocarcinoma and its tissue environment predicts prognosis. J Natl Cancer Inst. 2007;99(16):1257 PubMed -1269.

14. Brichory FM, Misek DE, Yim AM, et al. An immune response manifested by the common occurrence of annexins I and II autoantibodies and high circulating levels of IL-6 in lung cancer. Proc Natl Acad Sci U S A. 2001; 98(17):9824-9829.

15. Kaminska J, Kowalska M, Kotowicz B, et al.,Pretreatment serum levels of cytokines and cytokine receptors in patients with non-small cell lung cancer and correlations with clinicopathological features and prognosis. M-CSF - an independent prognostic factor, Oncology. 2006; 70 (2):115 PubMed -125 .

16. Orditura M, De Vita F, Catalano G, et al. Elevated serum levels of interleukin- 8 in advanced non-small cell lung cancer patients: relationship with prognosis. $J$ Interferon Cytokine Res. 2002;22 (11):1129-1135.

17. Yanagawa H, Sone S, Takahashi Y, et al. Serum levels of interleukin 6 in patients with lung cancer. Br J Cancer. 1995;71 (5):1095-1098. PubMed

18. Bermudez EA, Rifai N, Buring J, et al. Interrelationships among circulating interleukin-6, C-reactive protein and traditional cardiovascular risk factors in women. Arterioscler Thromb Vasc Biol. 2002;22 (10):1668-1673.

19. Kluft C, Leuven JA, Helmerhorst FM, et al., Pro-inflammatory effects of oestrogens during use of oral contraceptives and hormone replacement treatment, Vascul Pharmacol. 2002;39(3):149-154. PubMed

20. Takizawa H, Tanaka M, Takami K, et al. Increased expression of inflammatory mediators in small-airway epithelium from tobacco smokers. Am J Physiol Lung Cell Mol Physiol. 2000;278 (5):L906-L913.

21. Saito A, Suzuki HI, Horie M, et al. An integrated expression profiling reveals target genes of TGF-beta and TNF-alpha possibly mediated by microRNAs in lung cancer cells. PLoS One. 2013;8 (2):56587.

22. Pepys MB, Hirschfield GM. C-reactive protein: a critical update. J Clin Invest. 2003;111(12) :1805-12. PubMed 23. Bolayirly M, Turna H, Orhanoglu T, Ozaras R, Ilhan M, Ozguroglu M. C-reactive protein as an acute phase protein in cancer patients. Med Oncol. 2007;24(2):338 -44. 24. Sabatine MS, Morrow DA, Jablonski KA, Rice MM, Warnica JW, Domanski MJ, et al, Prognostic significance of the Centers for Disease Control/American Heart Association high-sensitivity $\mathrm{C}$-reactive protein cut points for cardiovascular and other outcomes in patients with stable coronary artery disease, Circulation. 2007;115(12):1528 PubMed -36.

25. Mahmoud FA, Rivera NI. The role of C-reactive protein as a prognostic indicator in advanced cancer. Curr Oncol Rep. 2002; 4(3):250 PubMed -5.

26. Wilop S, Crysandt M, Bendel M, Mahnken AH, Osieka $\mathrm{R}$, Jost $\mathrm{E}$, Correlation of C-reactive protein with survival and radiographic response to first-line platinum-based chemotherapy in advanced non-small cell lung cancer, Onkologie. 2008; 31(12):665 PubMed -70.

27. Chiu HM, Lin JT, Chen TH, Lee YC, Chiu YH, Liang JT, et al. Elevation of C-reactive protein level is associated with synchronous and advanced colorectal neoplasms in men. Am J Gastroenterol. 2008;103(9):2317 PubMed -25. 28. Koch A, Fohlin H, Sorenson S.Prognostic significance of C-reactive protein and smoking in patients with advanced non-small cell lung cancer treated with first-line palliative chemotherapy. J Thorac Oncol. 2009; 4 (3):326 -32. PubMed

29. lan S, zhiming L, shun L.Clinical significance of C-reactive protein in patients with stage I nonsmall cell lung cancer. Chin J Oncol. 2011;33 (6) :442-46. PubMed

30. Hara M, Yonei A, Ayabe T, Tomita M, Nakamura K, Onitsuka T. Postoperative serum C-reactive protein levels in non-small cell lung cancer patients. Ann Thorac Cardiovasc Surg. 2010;16 (2):85-90.

31. Allin KH, Bojesen SE, Nordestgaard BG.Baseline C-reactive protein is associated with incident cancer and survival in patients with cancer. J Clin Oncol. 2009;27 (13):2217 PubMed -2224.

32. Chaturvedi AK, Caporaso NE, Katki HA, et al. C-reactive protein and risk of lung cancer. J Clin Oncol. 2010;28 (6):2719 PubMed -2726.

33. Heikkila K, Ebrahim S, Lawlor DA. A systematic review of the association between circulating concentrations of $\mathrm{C}$ reactive protein and cancer. J Epidemiol Community Health. 2007;61(9): 824-833.

34. Siemes C, Visser LE, Coebergh JW, et al.C-reactive protein levels, variation in the C-reactive protein gene, and cancer risk: the Rotterdam Study. J Clin Oncol. 2006;24 (33):5216 PubMed -5222.

35. Trichopoulos D, Psaltopoulou T, Orfanos P, et al. 
Plasma C-reactive protein and risk of cancer: a prospective study from Greece. Cancer Epidemiol Biomarkers Prev. 2006;15(2):381-384.

36. Domagala-Kulawik J.The role of the immune system in non-small cell lung carcinoma and potential for therapeutic intervention. Transl Lung Cancer Res. 2015;4(2):177190.

37. Li J, Lan T, Zhang C, Zeng C, Hou J, et al. Reciprocal activation between IL-6/STAT3 and NOX4/Akt signalings promotes proliferation and survival of non-small cell lung cancer cells. Oncotarget. 2015 ; 6(2):1031-1048

38. Zhou B, Liu J, Wang ZM, Xi T C-reactive protein, interleukin 6 and lung cancer risk: a meta-analysis. PLOS One. 2012; 7(8); PubMed e43075.

39. Tarrant JM Blood cytokines as biomarkers of in vivo toxicity in preclinical safety assessment: considerations for their use. Toxicol Sci. 2010;117(1):4-16. PubMed

40. Cobos C, Figueroa JA, Mirandola L, Colombo M, Summers $G$, et al. The role of human papilloma virus (HPV) infection in non-anogenital cancer and the promise of immunotherapy: a review. Int Rev Immunol. 2014; 33 (5):383-401. PubMed

41. Vacchelli E, Aranda F, Bloy N, Buque A, Cremer I, et al.,Trial Watch-Immunostimulation with cytokines in cancer therapy. Oncoimmunology. 2016; 5(2): PubMed e1115942.

42. Lu H, Ouyang W, Huang C. Inflammation, a key event in cancer development. Mol Cancer Res. 2006; 4(4):221-233. PubMed

43. Su C, Zhou C, Zhou S, Xu J,Serum cytokine levels in patients with advanced non-small cell lung cancer: correlation with treatment response and survival. Med Oncol. 2011; 28(4):1453-1457. PubMed

44. Zou W. Immunosuppressive networks in the tumour environment and their therapeutic relevance. Nat Rev Cancer. 2005; 5(4):263-74.

45. Kinoshita T, Ito H and Miki C. Serum interleukin-6 level reflects the tumor proliferative activity in patients with colorectal carcinoma. Cancer. 1999; 85(12):2526-31. PubMed

46. Oka M, Iizuka N, Yamamoto K, Gondo T, Abe T, Hazama S, Akitomi Y, Koishihara Y, Ohsugi Y, Ooba Y, Ishihara $\mathrm{T}$, et al. The influence of interleukin- 6 on the growth of human esophageal cancer cell lines. I Interferon Cytokine Res.1996; 16(12): 1001-6.

47. Kawano M, Hirano T, Matsuda T, Taga T, Horii Y, Iwato $\mathrm{K}$, et al. Autocrine generation and requirement of BSF-2/IL-6 for human multiple myelomas. Nature.1988; 332(6159): 83-5. PubMed

48. Scott HR, McMillan DC, Forrest LM, et al. The systemic inflammatory response, weight loss, performance status and survival in patients with inoperable non-small cell lung cancer, Br J Cancer. 2002;87(3):264 PubMed -7.

49. Chung HW, Kim JW, Lee JH, Song Sy, Chung JB, $\mathrm{K} w o n \mathrm{OH}$, et al. Comparison of the validity of three biomarkers for gastric cancer screening: carcinoembryonic antigen, pepsinogens, and high sensitive C-reactive protein. J Clin Gastroenterol. 2009;43(1):19-26.

50. Lee JG, Cho BC, Bae MK, Lee CY, Park IK, Kim JD, et al. Preoperative C-reactive protein levels are associated with tumor size and lymphovascular invasion in resected nonsmall cell lung cancer. Lung Cancer. 2009;63 (1):106 PubMed -10

51. Hashimoto K, Ikeda Y, Korenaga D, et al, The impact of preoperative serum C-reactive protein on the prognosis of patients with hepatocellular carcinoma, Cancer. 2005;103(9): 1856 PubMed -64

52. Dalaveris E, Kerenidi T, Katsabeki-Katsafli A, et al. VEGF, TNF-alpha and 8-isoprostane levels in exhaled breath condensate and serum of patients with lung cancer. Lung Cancer. 2009;64 (2):219 PubMed -25.

53. Tas F, Duranyildiz D, Oguz H, et al. Serum vascular endothelial growth factor (VEGF) and bcl-2 levels in advanced stage non-small cell lung cancer. Cancer Invest. 2006;24 (6):576-80.

54. Lagiou P and Trichopoulos D. Inflammatory biomarkers and risk of lung cancer. J Natl Cancer Inst. 2011; 103(14):1073 PubMed -5

55. Pine SR, Mechanic LE, Enewold L, et al. Increased levels of circulating interleukin 6 , interleukin 8 , C-reactive protein, and risk of lung cancer. J Natl Cancer Inst. 2011;103 (14): 1112-22. PubMed

56. Boldrini L, Calcinai A, Samaritani E, et al.Tumour necrosis factor-alpha and transforming growth factor-beta are significantly associated with better prognosis in non-small cell lung carcinoma: putative relation with BCL-2-mediated neovascularisation. Br J Cancer. 2000;83:480-6 PubMed. 